JIKAP PGSD: Jurnal Ilmiah Ilmu Kependidikan

Vol,2. No,2. Tahun 2018

e-ISSN: 2597-4440 dan p-ISSN: 2597-4424

This work is licensed under a Creative Commons Attribution

4.0 International License

\title{
PENERAPAN MODEL PEMBELAJARAN KOOPERATIF TIPE TEAMS GAMES TOURNAMENT UNTUK MENINGKATKAN HASIL BELAJAR IPS SISWA SD INPRES 7/83 PASEMPE KABUPATEN BONE
}

\author{
Nurfaizah.AP ${ }^{1}$, A.Endang Kusuma Amir ${ }^{2}$ \\ Universitas Negeri Makassar \\ Email: ${ }^{1}$ nurfaizahap@gmail.com \\ ²endangkusumaamir@gmail.com
}

\begin{abstract}
Abstrak. Tujuan penelitian ini adalah untuk mendeskripsikan penerapan model Pembelajaran Kooperatif Tipe Teams Games Tournament (TGT) dalam meningkatkan hasil belajar IPS siswa kelas V SD Inpres 7/83 Pasempe Kecamatan Palakka Kabupaten Bone. Pendekatan penelitian menggunakan pendekatan kualitatif bersifat deskriptif. Jenis penelitian adalah penelitian tindakan kelas yang berdaur ulang atau siklus yaitu meliputi perencanaan, pelaksanaan, observasi dan refleksi. Fokus penelitian adalah penerapan pembelajaran kooperatif Tipe Teams Games Tournament dan hasil belajar IPS. Setting penelitian dilaksanakan di SD Inpres 7/83 Pasempe dan subjek penelitian ini adalah guru dan siswa. Teknik pengumpulan data dilakukan dengan observasi, tes dan dokumentasi Teknik analisis data adalah kualitatif yang terdiri dari tiga tahapan yakni reduksi data, penyajian data, dan penarikan kesimpulan. Hasil penelitian menunjukkan bahwa hasil belajar siswa mengalami peningkatan pada setiap siklus. Penerapan model pembelajaran kooperatif tipe TGT dapat meningkatkan aktivitas belajar siswa. Pada siklus I hasil belajar siswa berada pada kriteria sedang, pada siklus II berada pada kriteria tinggi Hasil belajar siswa dan aktivitas belajar siswa mengalami peningkatan setiap siklus karena terjadi perbaikan proses belajar pada setiap siklus. Berdasarkan hasil penelitian disimpulkan bahwa penerapan pembelajaran kooperatif tipe Teams Games Tournament dapat meningkatkan hasil belajar siswa dalam pembelajaran IPS di kelas V SD Inpres 7/83 Pasempe Kecamatan Palakka Kabupaten Bone.
\end{abstract}

Kata kunci: Pembelajaran kooperatif, Teams Games Tournament, Hasil belajar.

Abstract. The purpose of this study was to describe the application of the Teams Games Tournament (TGT) Cooperative Learning model in improving the social studies learning outcomes of fifth grade students of SD Inpres 7/83 Pasempe in Palakka District, Bone Regency. The research approach uses a descriptive qualitative approach. This type of research is classroom action research that recycles or cycles which includes planning, implementation, observation and reflection. The focus of the research is the application of cooperative learning Type Teams Games Tournament and social studies learning outcomes. The research setting was carried out at SD Inpres 7/83 Pasempe and the subject of this study were teachers and students. Data collection techniques carried out by observation, tests and documentation Data analysis techniques are qualitative which consists of three stages namely data reduction, data presentation, and conclusion drawing. The results showed that student learning outcomes had increased in each cycle. The application of the TGT cooperative learning model can improve student learning activities. 
In the first cycle student learning outcomes are on the medium criteria, in the second cycle are in high criteria Student learning outcomes and student learning activities have increased each cycle because there is an improvement in the learning process in each cycle. Based on the results of the study concluded that the application of cooperative learning type Teams Games Tournament can improve student learning outcomes in social studies learning in class V SD Inpres 7/83 Pasempe District Palakka Bone District.

Keywords: Cooperative Learning, Teams Games Tournament, Learning Outcomes.

\section{PENDAHULUAN}

Mata pelajaran IPS dirancang untuk mengembangkan kemampuan siswa agar menjadi anggota masyarakat yang memiliki pengetahuan, pemahaman dan kemampuan analisis terhadap kondisi sosial masyarakat dalam memasuki kehidupan bermasyarakat yang dinamis.

Oleh karena itu pelajaran IPS perlu disajikan secara sistamatis agar mudah dipahami oleh siswa, karena pada dasarnnya lingkungan kehidupan sekolah merupakan salah satu tempat terjadinya interaksi sosial yang sangat terkait dengan pembelajaran IPS yang mampu memberikan konstribusi yang besar untuk perkembangan siswa. Penerapan pembelajaran IPS dengan baik, maka siswa akan memiliki kehidupan sosial yang lebih baik.

Tujuan penerapan model pembelajaran dalam mata pelajaran IPS adalah untuk memperjelas penyajian guru dalam menyampaikan materi pelajaran, mengatasi sifat passif siswa dan mengatasi keterbatasan ruang sehingga pembelajaran menjadi efektif. Melalui model pembelajaran yang digunakan oleh guru maka hasil belajar siswa dapat meningkat. Namun dalam tataran empiris harapan tersebut tidak sesuai dengan kenyataan yang ada di sekolah dasar. selama ini masih banyak ditemukan disekolah, pelaksanaan pembelajaran IPS sangat membosankan karena penyajiannya bersifat monoton, hanya menggunakan metode ceramah bahkan sering ditemukan siswa mengalami kesulitan dalam memahami dan menjawab soal-soal IPS.

Berdasarkan informasi dan data yang diperoleh dari Kepala Sekolah dan Guru kelas V SD Inpres 7/83 Pasempe Kecamatan Palakka Kabupaten Bone, bahwa hasil belajar siswa pada mata pelajaran IPS masih sangat rendah, hanya 28,29\% nilai tuntas dari kriteria ketuntasan minimal (KKM) yakni 70 . Guna memperkuat data tersebut maka peneliti melakukan observasi atau pengamatan pada saat proses pembelajaran IPS berlangsung.
Berdasarkan hasil pengamatan, terungkap bahwa rendahnya hasil belajar IPS siswa disebabkan karena :1) Model pembelajaran yang digunakan guru masih bersifat konvensional atau pembelajaran masih berpusat pada guru sehingga Siswa kurang aktif pada saat proses pembelajaran berlangsung, 2), Guru kurang membangun kerjasama diantara siswa dalam proses pembelajaran sehingga Siswa kurang mampu bekerjasama pada saat pembelajaran kelompok.

Berdasarkan hasil observasi tersebut di atas dapat dipahami bahwa rendahnya hasil belajar siswa dalam pembelajaran IPS disebabkan oleh pendekatan pembelajaran yang digunakan oleh kurang sesuai, yakni pendekatan pembelajaran yang berpusat kepada guru sehingga mengakibatkan tingkat keaktifan siswa menjadi kurang. Siswa hanya diam mendengarkan guru berbicara di depan kelas dan pada akhirnya siswa bosan berada di dalam kelas. Siswa menunggu materi yang disampaikan oleh guru dan tidak mencari sendiri untuk memperdalam materi pembelajaran. Padahal pembelajaran di kelas perlu melakukan pendekatan pembelajaran yang berorientasi pada siswa aktif dan mandiri atau dengan kata lain menggunakan pendekatan student center. Siswa secara aktif mencari sendiri materi pembelajaran yang telah ditargetkan oleh guru.

Pembelajaran IPS akan lebih menarik apabila di dalam proses pembelajaran diterapkan suatu model pembelajaran yang sesuai dengan materi pembelajaran yang akan dipelajari. Pelaksanaan prosedur model cooperative learning dengan benar akan memungkinkan pendidik mengelola kelas dengan lebih efektif (Lie, 2002). Pembelajaran kooperatif adalah suatu metode belajar yang mengkondisikan siswa belajar, bekerjasama dan aktif berinteraksi dalam kelompok-kelompok kecil yang memenuhi lima unsur pokok pembelajaran kooperatif. Metode pembelajaran kooperatif, para siswa akan duduk bersama dalam kelompok yang beranggotakan empat orang untuk 
menguasai materi yang disampaikan oleh guru (Slavin, 2010). Lima unsur pokok tersebut adalah saling kebergantungan positif, tanggung jawab individual, interaksi personal, keahlian bekerjasama dan evaluasi proses kelompok. Kelompok pada pembelajaran kooperatif hanya terdiri dari empat sampai enam orang siswa.

Model pembelajaran kooperatif tipe Teams Games Tournament (TGT) salah satu tipe atau model pembelajaran kooperatif yang mudah diterapkan, melibatkan aktivitas seluruh siswa tanpa harus ada perbedaan status, melibatkan peran siswa sebagai tutor sebaya dan mengandung unsur permainan dan penguatan. Keunggulan pembelajaran tipe TGT adalah adanya turnamen akademik dalam proses pembelajaran. Dimana setiap anggota kelompok mewakili kelompoknya untuk melakukan turnamen (Tarigan, 2012). Karakteristik TGT yaitu siswa belajar dalam kelompok kecil dimana dalam proses pembelajaran terdapat games tournament yang nantinya akan ada penghargaan kelompok (Respati, 201). Aktivitas belajar dengan permainan yang dirancang dalam pembelajaran kooperatif model TGT memungkinkan siswa dapat belajar lebih rileks disamping menumbuhkan tanggung jawab, percaya diri, menghargai sesama, disiplin, kompetitif, sportif, kerja sama dan keterlibatan belajar seluruh siswa.

Alasan peneliti memilih menggunakan Tipe TGT dikarenakan dianggap dapat mengatasi masalah yang terjadi pada siswa saat pembelajaran IPS berlangsung. Menurut Slavin (Taniredja 2011: 56) bahwa "pembelajaran kooperatif adalah pembelajaran yang dilakukan secara berkelompok, siswa dalam satu kelas dijadikan kelompok-kelompok kecil yang terdiri dari 4 sampai 5 orang untuk memahami konsep yang difasilitasi oleh guru". Jadi pembelajaran kooperatif merupakan model pembelajaran yang mengutamakan kerjasama diantara siswa untuk mencapai tujuan pembelajaran. Model pembelajaran kooperatif memiliki ciri-ciri :1) untuk menuntaskan materi belajarnya, siswa belajar dalam kelompok secara koopertif, 2) kelompok di bentuk dari siswa yang memiliki kemampuan tinggi, sedang dan rendah, 3) jika dalam kelas terdapat siswa-siswa yang terdiri dari beberapa ras, suku, budaya, jenis kelamin yang berbeda, maka diupayakan agar tiap kelompok terdiri dari ras, suku, budaya, jenis kelamin yang berbeda pula, dan 4) penghargaan lebih di utamakan pada kerja kelompok daripada perorangan.
Menurut Parson (Slavin, 2010:167) bahwa $T G T$ adalah salah satu tekhnik terbaik apabila digunakan dalam kelas. Apa yang dilakukan TGT adalah memberikan kesempatan kepada guru untuk menggunakan kompetisi dalam suasana yang konstruktif/ positif. Para siswa menyadari bahwa kompetisi merupakan sesuatu yang mereka hadapi setiap saat, tetapi $T G T$ memberikan mereka peraturan dan strategi untuk bersaing sebagai individu setelah menerima bantuan dari teman-teman sejawatnya.Dengan mengacu pengertian Model TGT diasumsikan mampu memotivasi siswa dalam melaksanakan berbagai kegiatan sehingga merasa tertantang menyelesaikan tugas-tugasnya baik secara individu maupun kelompok dan juga dapat menumbuhkan sikap tanggungjawab, kerjasama, persaingan sehat serta keterlibatan belajar secara aktif.

Berdasarkan latar belakang yang telah dipaparkan sebelumnya, maka rumusan masalah dalam penelitian ini adalah Bagaimana penerapan Model Pembelajaran Kooperatif Tipe Teams Games Tournament (TGT) untuk meningkatkan hasil belajar IPS siswa kelas V SD Inpres 7/83 Pasempe Kecamatan Palakka Kabupaten Bone.

\section{METODE PENELITIAN}

Pendekatan penelitian menggunakan pendekatan kualitatif yang bersifat deskriptif, jenis penelitian adalah penelitian tindakan kelas yang berdaur ulang atau siklus yaitu meliputi perencanaan, pelaksanaan, observasi dan refleksi. Fokus penelitian adalah Penerapan pembelajaran kooperatif Tipe Teams Games Tournament dan Hasil belajar IPS. Setting penelitian dilaksanakan di SD Inpres 7/83 Pasempe dan subjek penelitian ini adalah guru dan seluruh siswakelas V. Teknik pengumpulan data dilakukan dengan observasi, tes dan dokumentasi. Teknik analisis data adalah reduksi data yang sudah dikumpulkan diproses, diseleksi,difokuskan dan disederhanakan.Ukuran keberhasilan dapat dilihat dari dua aspek,yaitu aspek proses dan hasil. Keberhasilan guru dapat dilihat pada kemampuan mengimplementasikan perencanaan pembelajaran ,sedangkan keberhasilan siswa dapat dilihat pada kemampanaktivitas dalampembelajaran dan hasil belajarnya. Berdasarkan kriteria tersebut di atas maka ditetapkan kriteria keberhasilan tindakan pada penelitian ini secara klasikal telah meningkat pada setiap siklus dan menunjukkan tingkat pencapaian $\geq 75 \%$. 


\section{HASIL DAN PEMBAHASAN}

Berdasarkan hasil analisis dan refleksi siklus I, bahwa proses belajar IPS dengan menerapkan model pembelajaran kooperatif tipe TGT sudah terlaksana dengan kategori cukup sedangkan hasil belajar belum mencapai indikator keberhasilan yang sudah ditetapkan.

Hasil analisis data dan refleksi siklus II yang dilakukan oleh peneliti dan pengamat sesuai dengan observasi yang sudah dilakukan selama tindakan siklus II berlangsung, dengan mengacu pada kriteria standar keberhasilan tindakan yang sudah ditetapkan maka pelaksanaan siklus II disimpulkan telah berhasil dengan kategori baik, sehingga tindakan perbaikan hasil belajar siswa di kelas V SD Inpres 7/83 Pasempe Kec. Palakka Kab. Bone dinyatakan selesai.

Aktifitas dalam pembelajaran kooperatif tipe TGT memungkinkan siswa dapat belajar lebih semangat, selain itu dapat pula menumbuhkan tanggung jawab, kerjasama, persaingan sehat serta keterlibatan belajar secara aktif. Dalam menyelesaikan tugas kelompok, setiap anggota saling bekerjasama dan membantu dalam memahami bahan pembelajaran. Terdapat 4 tahap dalam Tipe TGT yaitu pengajaran, belajar tim, turnamen dan rekognisi tim.

Pelaksanaan pembelajaran dengan menggunakan Tipe TGT yang digunakan peneliti merupakan hal yang baru bagi siswa sehingga mereka merasa senang dalam mengikuti pembelajaran tersebut. Dalam TGT ini menekankan kepada guru untuk melatih keterampilan siswa selangkah demi selangkah dengan banyaknya pertanyaan, latihan soal dan kerjasama tim dalam pembelajaran tersebut.

Kegiatan pembelajaran pada tindakan siklus I dengan menggunakan Tipe TGT masih belum berjalan secara optimal. Pada tindakan siklus I guru juga kurang membimbing siswa dalam memahami pelajaran yang ada sehingga banyak siswa yang kurang memperhatikan materi yang ada. Sehingga hanya $60 \%$ siswa yang tuntas. Hasil tes ini masih belum sesuai dengan indikator keberhasilan yang telah ditetapkan oleh peneliti. Sehingga perlu diperhatikan upaya untuk peningkatan pemahaman siswa pada tindakan siklus II dengan berpedoman pada kekurangankekurangan yang ada untuk ditingkatkan dan keberhasilan yang dilakukan pada tindakan siklus I tetap dipertahankan pada tindakan siklus II.
Pengimplementasian Tipe TGT pada pelaksanaan siklus II dilakukan secara optimal, ini terlihat pada proses pembelajaran guru mampu mengungkap pengetahuan awal siswa lebih baik dari yang sebelumnya sehingga siswa termotivasi dalam menghubungkan materi yang ada dengan materi sebelumnya, serta guru juga sudah lebih baik dalam membimbing siswanya sehingga materi-materi yang sulit dapat diulang kembali oleh guru sehingga pada saat membimbing siswa masih ikut termotivasi dalam pembelajaran. Dengan perbaikan yang dilakukan pada tindakan siklus II dan adanya motivasi yang sering dilakukan oleh guru sehingga siswa dapat menjawab pertanyaan pada tes akhir siklus II dengan baik. Kondisi pembelajaran pada pelaksanaan siklus II mengalami peningkatan pemahaman.

Keberhasilan pelaksanaan perbaikan pengajaran pada siklus II terlihat dari hasil belajar siswa kelas V SD Inpres 7/83 Pasempe Kecamatan Palakka Kabupaten Bone pada tes akhir siklus yang dilakukan pada kegiatan akhir pembelajaran dengan nilai rata-rata kelas 70 dengan kualifikasi baik. Keberhasilan ini didasarkan atas kriteria standar keberhasilan penelitian yang ditetapkan yakni, hasil belajar siswa secara individu meningkat dengan pencapaian nilai 70 serta ketuntasan belajar kelas minimal 75\%. Penggunaan Tipe Teams Games Tournament (TGT) menunjukkan bahwa ada peningkatan hasil belajar pada setiap siklus, namun pada saat penelitian tindakan siklus I terlihat dari hasil belajar siswa yang mengalami peningkatan pada siklus I meningkat menjadi kualifikasi cukup tetapi belum sesuai dengan indikator keberhasilan yang telah ditetapkan, selanjutnya pada tindakan siklus II meningkat lagi menjadi kualifikasi baik . Dengan demikian berdasarkan hal-hal tersebut diatas maka dapat disimpulkan bahwa penggunaan Tipe Teams Games Tournament pada mata pelajaran IPS telah memberikan dampak pada peningkatan hasil belajar siswa.

\section{SIMPULAN DAN SARAN}

Berdasarkan rumsan masalah, pelaksanaan tindakan serta analisis data maka dapat disimpulkan bahwa hasil belajar IPS siswa kelas V SD Inpres 7/83 Pasempe Kecamatan Palakka Kabupaten Bone melalui penerapan pembelajaran kooperatif tipe Teams Games Tournament (TGT) mengalami peningkatan sebagaimana yang diharapkan. Hal tersebut 
JIKAP PGSD: Jurnal Ilmiah Ilmu Kependidikan

dapat dilihat dari hasil belajar siswa pada tindakan siklus I dengan kualifikasi cukup dan meningkat pada tindakan siklus II dengan kualifikasi baik.

Perlunya peningkatan kualitas mengajar guru dengan menerapkan Tipe pembelajaran yang sesuai dengan karakter serta kebutuhan siswa seperti penggunaan model pembelajaran kooperatif tipe Team Games Tournament (TGT) karena hal ini dibuktikan saat digunakan pada kegiatan penelitian dapat meningkatkan hasil belajar siswa khususnya pada mata pelajaran IPS

\section{DAFTAR RUJUKAN}

Arikunto dkk. 2011. Penelitian Tindakan Kelas. Jakarta: Bumi Aksara

Arikunto dan Cepi Safruddin Abdul Jabar. 2007. Evaluasi Program Pendidikan Pedoman Teoretis Praktis Bagi Praktisi Pendidikan. Jakarta: Bumi Aksara.

Depdiknas. 2006. Kurikulum Tingkat Satuan Pendidikan (KTSP) untuk SD/MI. Jakarta: Depdiknas.

Gunawan, Rudy. 2011. Pendidikan IPS Filosofi, Konsep dan Aplikasi. Bandung: . Alfabeta

Hamzah, Ali. 2014. Perencanaan dan Strategi Pembelajaran Matematika. Jakarta: Grafindo

Paizaluddin, dkk. 2013. Penelitian Tindakan Kelas Panduan Teoritis dan Praktis.Bandung: Alfabeta.

Rusman. 2012. Tipe-Tipe Pembelajaran "Mengembangkan Profesionalisme Guru”. Bandung : Rajagrafindo Persada.

Slavin, R.E. 2010. Cooperative Learning "Teori, Riset dan Praktik".Bandung: Nusa Media.

Soleha. 2010. Proses Kerja Sama Tim dalam Mengembangkan Perpustakaan Sekolah Studi Kasus Pada SDN Pancoran 08 Jakarta. Skripsi. Depok. Program Studi Ilmu Perpustakaan

Sugiyono. 2008. Memahami Penelitian Kualitatif. Bandung: Alfabeta.

Susanto, Ahmad. 2013. Teori belajar dan pembelajaran di Sekolah Dasar. Jakarta: Kencana Prenada Media Grup.

Suprijono, Agus. 2009. Cooperative Learning "Teori dan Aplikasi Paikem”.Yogyakarta. Pustaka Belajar.
Taniredja, Tukiran, dkk. 2011. Model-model Pembelajaran Inovatif. Bandung. Alfabeta.

Thobroni, Arif Mustafa. 2013. Belajar dan Pembelajaran Pengembangan Wacana dan praktik Pembelajaran dalam Pembangunan Nasional. Jogjakarta : ArRuzz Media

Trianto. 2009. Mendesain Model Pembelajarran Inovatif-Progresif: Konsep, Landasan, dan Implementasi pada Kurikulum Tingkat Satuan Pendidikan (KTSP). Jakarta: Kencana

Wisnu D. Yudianto. Journal of Mechanical Engineering Education, Vol.1, No.2, Desember 2014 